\title{
Author Correction: Thyroid hormone induces progression and invasiveness of squamous cell carcinomas by promoting a ZEB-1/E-cadherin switch
}

\author{
Caterina Miro, Emery Di Cicco, Raffaele Ambrosio, Giuseppina Mancino, Daniela Di Girolamo, \\ Annunziata Gaetana Cicatiello, Serena Sagliocchi, Annarita Nappi, Maria Angela De Stefano, Cristina Luongo, \\ Dario Antonini, Feliciano Visconte, Silvia Varricchio, Gennaro Ilardi @, Luigi Del Vecchio, Stefania Staibano, \\ Anita Boelen, Cedric Blanpain (D), Caterina Missero (D, Domenico Salvatore \& Monica Dentice
}

Correction to: Nature Communications https:/doi.org/10.1038/s41467-019-13140-2, published online 27 November 2019.

The original version of this Article contained an error in the author affiliations. Silvia Varricchio, Gennaro Ilardi and Stefania Staibanow were incorrectly associated with 'Department of Public Health, University of Naples "Federico II", Naples, Italy' instead of the correct 'Department of Advanced Biomedical Sciences, University of Naples "Federico II", Naples, Italy.' This has now been corrected in both the PDF and HTML versions of the Article.

Published online: 08 January 2020

\footnotetext{
(c) (i) Open Access This article is licensed under a Creative Commons Attribution 4.0 International License, which permits use, sharing, adaptation, distribution and reproduction in any medium or format, as long as you give appropriate credit to the original author(s) and the source, provide a link to the Creative Commons license, and indicate if changes were made. The images or other third party material in this article are included in the article's Creative Commons license, unless indicated otherwise in a credit line to the material. If material is not included in the article's Creative Commons license and your intended use is not permitted by statutory regulation or exceeds the permitted use, you will need to obtain permission directly from the copyright holder. To view a copy of this license, visit http://creativecommons.org/licenses/by/4.0/.
}

() The Author(s) 2020 